The current issue and full text archive of this journal is available on AFEBI Management and Business Review at:

https://journal.afebi.org/index.php/ambr/article/view/402

\title{
MANAGEMENT OF OCCUPATIONAL HEALTH AND SAFETY DURING THE COVID-19 PANDEMIC: FACTS AND CHALLENGES
}

\author{
Wahyuni Diah Ekasari* \\ Universitas Terbuka, Indonesia \\ Suharnomo \\ Universitas Diponegoro, Indonesia \\ Intiyas Utami \\ Universitas Kristen Satya Wacana, Indonesia
}

\author{
Management of \\ Occupational \\ Health and Safety \\ During The Covid- \\ 19 Pandemic: Facts \\ and Challenges
}

\begin{abstract}
The COVID-19 pandemic has resulted in drastic changes as well as losses for the business world. This causes various companies to carry out occupational safety and health procedures for their employees. The purpose of this research is to dig deeper and understand the policies for managing occupational health and safety during the COVID-19 pandemic, implementation, challenges, and solutions. The number of informants in this study was ten people, including five subject informants and five informants for triangulation. Data analysis was performed using the qualitative data analysis method with the critical phenomenology approach of the Stevick-Colaizzi-Keen model. This study modifies that is both use the theory of occupational health and safety which is modified into Occupational Health and Safety regulations known as strict 5M health protocol doe to COVID-19 pandemic. The results of the analysis show that the management of occupational health and safety during the COVID-19 pandemic at the Rembang post has been carried out properly office by implementing the $5 \mathrm{M}$ health protocol, namely putting on mask, washing hands, social distancing, staying away from crowds, and reducing mobility, according to the Circular of the Ministry of Manpower Number B.5/51/AS.0202/I/2020 to urge people not to cause the spread of the COVID19 cluster in the work environment of Rembang Post Office.
\end{abstract}

Keywords: Occupational Health, Work Safety, 5M Health Protocol, Job Satisfaction, Performance, Rembang Post Office

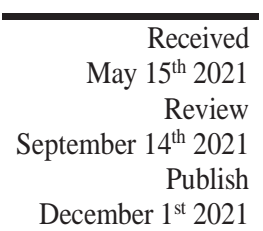

December $1^{\text {st }} 2021$

\footnotetext{
*Corresponding author. Email address: wahyunidiah.ekasari@gmail.com
}

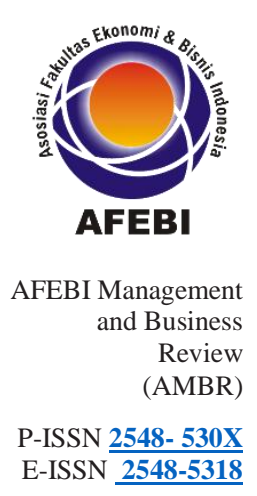


Humans acts as a subject that must be considered by entrepreneurs and corporate leaders. A healthy workforce is essential for sustainable social and economic development at the global, national, regional, and local levels (Sewu et al., 2019). A healthy and safe workplace is the basis for achieving higher productivity and performance and enhancing a quality work life for the employees.

Several studies state that occupational health provides direct benefits to employee performance which in turn can increase organizational productivity. Safety and risk management procedures, occupational safety and health regulations, and organizational commitment have an indirect effect on employee performance (Kaynak et al., 2016). Occupational health and safety indirectly have a significant effect on employee performance through job satisfaction as an intervening variable (Wibowo \& Utomo, 2016). Emotional intelligence and work health simultaneously affect employee performance (Purnama, 2017). Occupational health and safety, work environment, and discipline have simultaneous partial effects on employee performance (Putri et al., 2018). Work security, work safety, and occupational health affect employee performance (Safriansyah \& Naim, 2019). Meanwhile, Sewu et al. (2019) stated that there is a positive correlation between occupational safety and health on bank performance.

However, there are several studies that have slightly different results from the above studies. Ahmad et al. (2017) stated that workers who are dissatisfied with their work can perform poorly even though occupational safety and health practices have been carried out well in their workplace. Occupational health and safety does not have a direct effect on employee performance (Ekowati \& Amin, 2018). Occupational health and safety management systems can improve occupational health and safety conditions and support the creation of a healthy and safe workplace (Mohammadfam et al., 2017). Meanwhile, Sembe \& Ayuo (2017) stated that the combined effects of psychological, health, and safety factors significantly affect the level of employee job satisfaction.

In the beginning of 2020, a global pandemic which was quite disturbing for the public had spread, namely the COVID-19, had an impact on social, economic, and health orders. The COVID-19 has resulted in a global crisis. A crisis is an event that will lead to an unstable and dangerous situation that affects individuals, groups, communities, or the entire society (Goniewicz, 2020). Crises are perceived as negative changes in security, economic, political, social, or environmental issues, especially when they occur suddenly with little or no warning. On March 2, 2020, the first case of the COVID-19 was found in Indonesia and since then, various efforts have been made to prevent the spread of the COVID-19, including in the work environment. Efforts to prevent the COVID-19 at work sites include complying with regulations related to Occupational Safety and Health (OSH).

The Directorate General of Labor Inspection and K3 issued a Circular Number B.5/51/AS.0202/I/2020 which urges all heads of the Manpower Office and company leaders to be aware of the spread of severe pneumonia with unknown causes in workers. This circular also applies to PT Pos Indonesia (Persero) Rembang, which is the brach of one of the state-owned companies engaged in postal and current account services which operate in Indonesian and international regions. PT Pos Indonesia (Persero) Rembang is committed to carrying out health protocols in order to provide maximum protection for employees, their families, and even postal customers.

PT Pos Indonesia (Persero) during the COVID-19 pandemic also assumed the task of distributing cash social assistance from the Ministry of Social Affairs. The distribution of cash social assistance by PT Pos Indonesia (Persero) was carried out through the cash social assistance channels at the post office, at the community level, and directly to the residents. Cash social assistance is cash assistance provided to poor, underprivileged, and/or vulnerable families who are affected by the COVID-19 outbreak.

From the web source https://rembangkab.go.id/bansos-bantuan-social/, Rembang Post Office was assigned the task of distributing cash social assistance funds from the Ministry of Social Affairs in several phases: phase I with an allocation of 33,897 beneficiary families (KPM), phase II of 33,897 KPM, phase III of 33,894 KPM, phase IV of 32,259 KPM, phase V of 32,259 KPM, phase VI of 32,321, and phase VII of 32,855 KPM (see Table 1. Data on the Number of KPM Through Rembang Post Office).

This task was not easy because Rembang is a small district with limited hospitals/health facilities and a limited number of post office employees. The Rembang Post Office area itself is not large but they must be able to distribute the cash social assistance funds to tens of thousands of KPM during the COVID-19 pandemic. Meanwhile, the number of confirmed COVID-19 cases in Rembang Regency continued to increase every month (see Figure 1. Data on the Development of COVID-19 Cases in Rembang Regency). With the obligation to comply with regulations related to occupational safety and health in a disciplined manner, workers were familiar with the term, but strictly adhering to health protocols so as not to become a cluster for the spread of the COVID-19 was not easy. This had become a separate problem, with the social distancing, the adequacy of the place for washing hands with a soap, the speed of service at the time of fund disbursement, and the data on the fund allocation reaching tens of thousands of cash social assistance recipients. 


\begin{tabular}{|c|c|c|}
\hline Phase & Month & KPM \\
\hline I & April 2020 & 33.987 \\
\hline II & May 2020 & 33.987 \\
\hline II & June 2020 & 33.894 \\
\hline IV & August 2020 & 32.259 \\
\hline V & August 2020 & 32.259 \\
\hline VI & September 2020 & 32.321 \\
\hline VII & October 2020 & 32.855 \\
\hline
\end{tabular}

Source: https://rembangkab.go.id/bansos-bantuan-sosial/

\section{Management of Occupational Health and Safety During The Covid-19 Pandemic: Facts and Challenges}

Table 1.

Data on the Number of KPM Through Rembang

Post Office

Figure 1.

Data on the

Development of COVID-19 Cases in Rembang

Regency

The research aims to dig deeper and understand the policies of occupational health and safety management during the COVID-19 pandemic at Rembang Post Office, its implementation, challenges, and solutions. The application of this model from the previous ones is different in the way it compares the implementation of occupational health and safety management in the period before and after the COVID-19 pandemic. However, in the implementation of this research, the elements of occupational health and safety were modified into $5 \mathrm{M}$ health protocol regulations which will encourage companies to be disciplined and to innovate to improve their performance during the pandemic. This is a topic that has not been much discussed by previous reseachers

\section{LITERATURE STUDY}

\section{Occupational Health}

Panggabean (2016) stated that health refers to the freedom of employees from illness physically or mentally. Health is the most important element so that we can enjoy a quality life, both at home and at work. Health is also the most important factor in maintaining the survival of an organization or company. Meanwhile, Purnama (2017) stated that occupational health is a part of health science which aims to make workers obtain physical, mental, and social health conditions so that it is possible to work optimally. Ekowati and Amin (2018) stated that occupational health is freedom both physically and emotionally. Wibowo and Utomo (2016) stated that occupational health is an effort to guarantee and maintain the health, physical, and spiritual integrity of workers, especially humans, towards a just and prosperous society. From some of the definitions above, it can be concluded that occupational health is an effort to ensure and maintain health conditions physically, mentally, and socially so that it is possible to work optimally for the achievement of a just and prosperous society.

According to the International Labor Organization (ILO), occupational safety and health is the promotion and maintenance of the highest degree of physical, mental, and social well-being of all workers in all types of work, preventing occupational health problems (https://www.ilo.org/global/publications). Workers should be protected in each job from risks arising from factors that can interfere with health, also placed and maintained in a work environment that is in accordance with their physiological and psychological conditions so they can fit well with their work and duties.

\section{Work Safety}

Panggabean (2016) stated that work safety is protection for employees from accidents while carrying out their duties and responsibilities at work. Matters included in the scope of work safety include all factors related to injury, repeated stress, and violence at work and in the household.

Sari (2018) stated that work safety is the protection of work security experienced by workers, both physically and mentally in the work environment. Meanwhile, Panggabean (2016) stated that work safety is an instrument that protects workers, companies, the environment, and the surrounding community from hazards 
due to work accidents. From several definitions of work safety above, it can be concluded that work safety is the process of protecting employees, companies, the environment, and the community against injuries, stress, violence, and hazards that arise in the work environment.

Occupational health and safety is the promotion and maintenance of the highest degree of physical, mental, and social well-being of all occupation; the prevention among workers of departures from health caused by their working conditions; the protection of workers in their employment against risks due to factors detrimental to health; the placing and maintenance of workers in an occupational environment adapted to his physiological and psychological equipment to summarize the adaptation of work for them and each of them to their job.

\section{M Health Protocol}

In Indonesia, the number of positive cases of the COVID-19 has approached 1.5 million people (18/03/2021). The good news is that around 1.3 million people have recovered from the SARS-CoV-2 virus that causes the COVID-19. However, unfortunately, 40,449 thousand people have lost their lives due to the virus. Defeating the spread and transmission of COVID-19 in the world is not easy. However, various efforts continue to be made by experts and the global population to end the threat of the coronavirus.

In several countries, the government has developed health guidelines and protocols to deal with the COVID-19. In Indonesia, this health protocol is known as 5M that means washing hands, putting on mask, social distancing, staying away from the crowd, and reducing mobility (source:https://padk.kemkes.go.id.).

\section{Washing Hands}

Routinely washing hands thoroughly is one of the health protocols that is quite effective in preventing COVID-19 transmission. For maximum results, people need to wash hands for at least 20 seconds after doing an activity. To kill viruses and other germs, people should wash their hands with water and soap or apply hand sanitizer with at least 60 percent alcohol.

\section{Putting on Mask}

At the beginning of the COVID-19 pandemic last year, the World Health Organization (WHO) stated that the use of masks was only recommended for sick people, not healthy people. However, the SARS-CoV-2 virus is completely new, so health protocols can change over time. Sometime after the release of the policy above, WHO finally issued an appeal for everyone (whether healthy or sick) to always use a mask when doing activities outside the house.

\section{Social Distancing}

Social distancing means keeping a minimum distance of 1 meter from other people to avoid getting droplets from people while talking, coughing, or sneezing and avoiding crowds. If it is not possible to maintain a distance, various administrative and technical engineering can be carried out. Administrative engineering can be in the forms of limiting the number of people, setting schedules, and so on. Meanwhile, technical engineering, among others, can be in the forms of partitioning, setting entrances and exit routes, and so on.

\section{Staying Away from the Crowd}

Apart from the three things above, staying away from the crowd is a health protocol that must also be done. According to the Indonesian Ministry of Health, people are asked to stay away from the crowd when they are outside the house. The more often people meet each other, the higher the chance of being infected with the coronavirus. Therefore, people are urged to avoid crowded places, especially when they are sick or over 60 years old (elderly). According to research, the elderly and people with chronic diseases have a higher risk of contracting the coronavirus.

\section{Reducing Mobility}

The coronavirus that causes the COVID-19 can be anywhere. So, the more time people spend outdoors, the higher their exposure to this evil virus. Therefore, if there is no urgent need, people should stay at home. According to the Ministry of Health, even though someone is healthy and has no symptoms of disease, it is not certain that they go home with the same condition. The reason is because the coronavirus can spread and infect someone quickly.

\section{Rembang Post Office}

The main activities of the branch post office are making job descriptions at the branch post offices in accordance with the applicable regulations as work guidelines; ensuring that the implementation of work at the branch post office is in accordance with the SOP and company regulations; receiving transactions for package services, agency, BPM (postage stamp) and philatelic products, mail services, financial services, savings, current accounts and fund distribution, pension payments, and postal money orders; responsible for financial receipt and expenditure transactions that occur at the branch post office on the N2 insurance list; making requests for postal goods, stamps, and philatelic products; packing the letters and packages that will be sent to the relevant checking post office every day in accordance with the closing schedule determined by the Inspection Post Office; matching the amount of money from the receipt and payment of financial transactions at the branch post office with related 
manuscripts and source documents; sending the manuscripts of financial coverage, source documents, transaction receipts together with postal items in post bags to the Inspecting Post Office; opening a postal bag received from the examiner's post office in front of the witness; and supervising the delivery of letters and packages carried out by postal courier at the post branch offices as well as the inspection of remaining deliveries. The following is a picture of the organizational structure of Rembang Post Office:

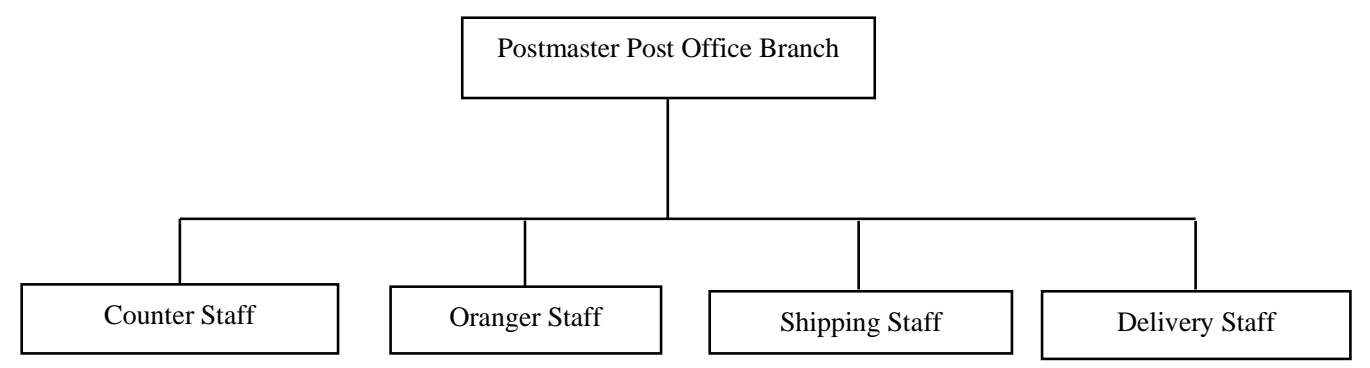

The researcher chose this post office branch over other places because this post office is located at JL. Diponegoro No. 61, Tasik Agung Village, Rembang District, Rembang Regency, only has 11 employees, and the office space is not too large, has the task of distributing cash and social assistance from the Ministry of Social Affairs reaching thirty thousand KPM, with the obligation to strictly implement the 5M health protocol. The researchers chose to research post offices rather than other places because the post office as one of the state-owned companies is committed to always protecting both employees, postal customers, and also the environment so that they are not exposed to the COVID-19 virus and do not become a cluster of the spread of COVID-19. Until now there has been no research on COVID-19 at the post office related to the completion of COVID-19 cases.

\section{Job Satisfaction}

Job satisfaction is a person's perspective, both positive and negative, on the job that has been given (Nurmaningsih and Wahyono, 2017). Employees who are satisfied with the company will provide remuneration for the company by maximizing their performance. Ahmad et al. (2017) stated that job satisfaction is the psychological state of employees at work when their needs and aspirations are met and they feel satisfied and happy.

Wibowo (2016) stated that job satisfaction is an attitude of enjoying at work, outside of work, and a combination of inside and outside of work which is reflected by work morale, discipline, and performance. Meanwhile, Sembe and Ayuo (2017) defined job satisfaction as a combination of cognitive, affective, and behavioral states that cause a person to feel satisfied with their job. From some of the definitions of job satisfaction above, the authors concluded that job satisfaction is a way of seeing someone enjoying at work and outside of work that causes someone to feel satisfied with their work and can affect their performance results.

\section{Performance}

Some sources state that the term "performance" has been known since the imperial period of the Wei dynasty in 221-265 AD. Sobirin (2016) stated that the understanding and meaning of performance are as follows: 1) performance is something that can be measured, whether using numbers or an expression that allows communication to occur; 2) performance means striving in accordance with a specific purpose to produce something; 3) performance is the result of an action; 4) performance is the ability to produce or the potential to create; 5) performance is a comparison between the results and certain benchmarks, both internally and externally; 6) performance is an unexpected (surprising) outcome compared to an expected one; 7) in the discipline of psychology, performance is acting out; 8) performance is a performance, especially in performing arts, which involves the actors, their roles, and how the roles are played and involving outsiders who watch the performance; 9) performance is a decision or judgment which is based on something else as a comparison.

Sariansyah and Naim (2019) said that employee performance is the result of work in quality and quantity achieved by an employee in carrying out his duties in accordance with the responsibilities assigned to him. Meanwhile, Wibowo and Utomo (2016) argued that performance is a series of results obtained by an employee during a certain period of time and does not include the personal characteristics of the employee being assessed. Sobirin (2016) considered performance as events that occur simultaneously involving actions, the results of these actions, and the comparison between the results of the actions with certain measures or benchmarks.

Ahmad et al. (2017) stated that performance is the result obtained by a person or group in an organization in the form of what they do or do not do. Based on the understanding of the experts above, the authors conclude that performance is the result or level of success that has been achieved by a person or group within the organization as a whole during a certain period which has a positive impact on improving the company performance in achieving organizational goals.
Management of Occupational Health and Safety During The Covid-19

Pandemic: Facts and Challenges

Figure 2.

Post Office

Organizational Structure 
Existing variables were adopted from previous studies (Wibowo \& Utomo, 2016; Ahmad et al., 2017; Ekowati \& Amin, 2018). In contrast, the model developed in this study is a new concept of occupational health and safety management during the COVID-19 pandemic with the 5M health protocol. The study of occupational safety and health in previous studies refers to occupational safety and health variables that have a significant effect on employee performance through job satisfaction as an intervening variable. However, the model developed which was applied to this study is the existence of a Covid-19 pandemic which requires every employee to strictly discipline the $5 \mathrm{M}$ health protocol. Figure 1, which is a research and analysis framework, to formulate a hypothesis

Figure 3.

Research and Analysis Framework
Table 2.

Informants is described as follows:

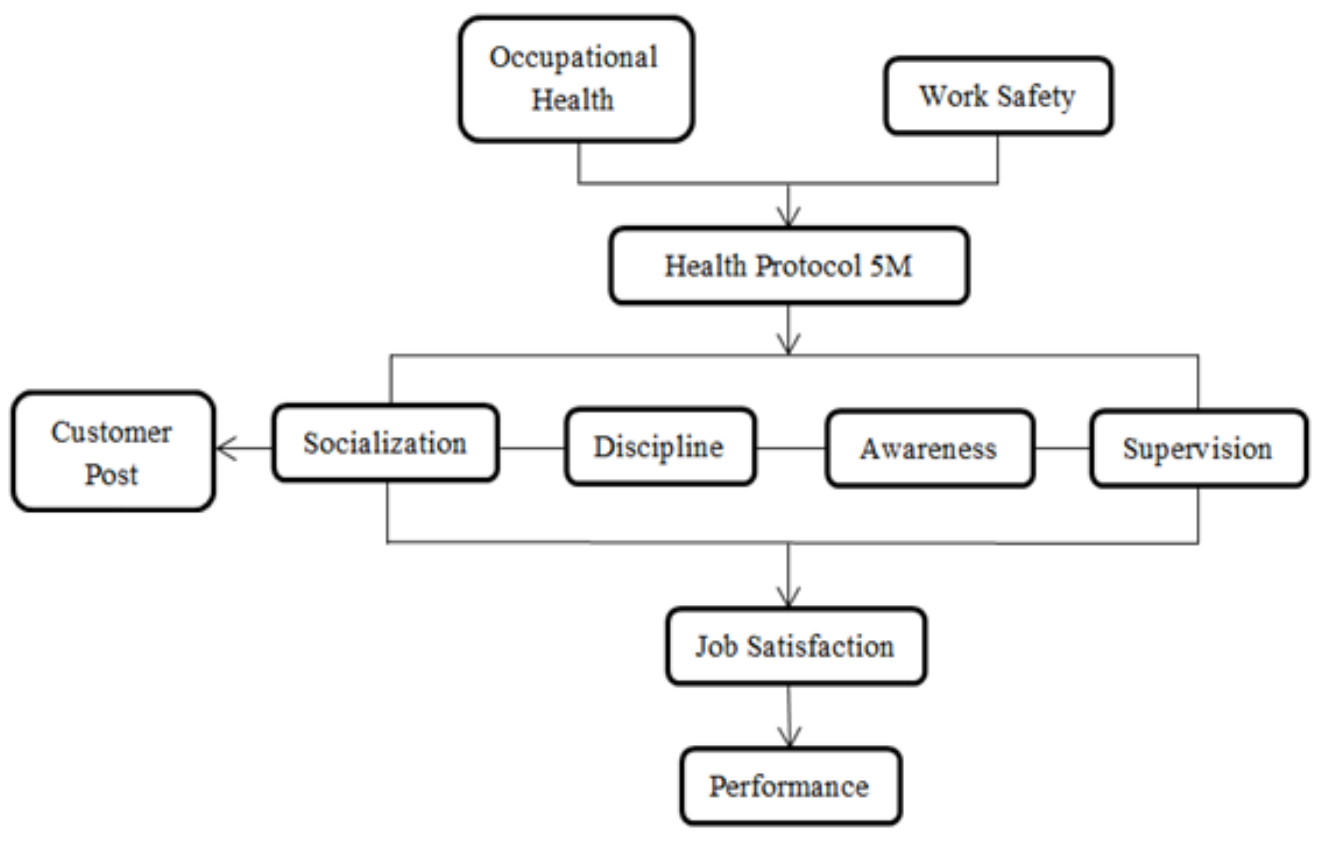

\section{RESEARCH METHODOLOGY}

This study used primary data and secondary data. According to Hamzah (2020) primary data were data obtained by the researchers through interview and observation by seeing and observing directly the conditions in the field so that the researchers got a broader picture of the problem being researched. Meanwhile, secondary data were obtained from non-human sources, including photographs, documents, and statistical materials. The researcher did not get permission to obtain daily consumer data at the Rembang branch post office, so this study used informants as research samples and used interview techniques to collect primary data.

The interview was carried out to obtain the general description of Rembang Post Office, the occupational health and safety management policies implemented at Rembang Post Office, the implementation of health protocols in Rembang Post Office, the obstacles faced due to the health. protocols, and the solutions to overcome the obstacles to implementing health protocols. This study used the informants' responses as the research sample. As for those who became informants in this study were ten people consisting of five people as subjective informants, namely employees of Rembang Post Office, and five people as triangulation informants, namely the Head of P2 Rembang Regency Health Office and four post office customers (see Table 2. Informants). The qualitative data analysis was performed using a critical phenomenology approach using the Stevick-Colaizzi-Keen model.

\begin{tabular}{|c|l|c|}
\hline No. & \multicolumn{1}{|c|}{ Status } & Amount \\
\hline 1 & Postmaster Rembang Branch Office & 1 \\
\hline 2 & Rembang Post Office Employee; & 2 \\
& a. Rembang branch post counter clerk & 1 \\
& b. Postal courier & 1 \\
\hline 3 & c. Oranger Post & 4 \\
\hline 4 & Rembang branch postal customer & $\mathbf{1 0}$ \\
\hline \multicolumn{2}{|c|}{ Amount } \\
\hline
\end{tabular}

The qualitative data analysis with a critical phenomenology approach using the Stevick-Colaizzi-Keen model was adjusted to the stages of this study as follows: 1) providing complete descriptions of events/phenomena experienced directly by the informants; 2) examining and recording each statement of the informants, make a list 
based on the statements, grouping them into certain themes, combining descriptions and structures to determine the meaning and essence of the phenomena; and 3) making a comprehensive explanation of each meaning and essence of the phenomena (Hamzah, 2020)

\section{RESULT AND DISCUSSION}

\section{Occupational Health and Safety Management Policies During the COVID-19 Pandemic at Rembang Post Office}

Prior to the Covid-19 pandemic, the management of Occupational Health and Safety at the Rembang branch post office included:postal courier officers and postal clerks were required to wear helmets, wear jackets, carry SIM and STNK when carrying out their duties. For the Rembang branch post office counter staff, there is no obligation to wearing mask and wash hands. For customers of the Rembang post office, there is no obligation to putting on mask and washing hands when coming to the post office, there is no distance between seats when queuing. The Rembang post office does not provide hand washing facilities near the post office entrance. It can be concluded that prior to the Covid-19 pandemic the 5M health protocol was not implemented at the Rembang branch post office.

Positive cases of COVID-19 in Indonesia in general and positive cases of COVID-19 in Rembang Regency in particular have not shown a declining graph to date. In line with the steps to prevent the spread of the COVID-19 that are continuously being developed by the government, PT Pos Indonesia (Persero) has consistently attempted to minimize the spread of the COVID-19 virus in the post office environment to protect post officers and customers. Rembang Post Office implements all occupational safety and health regulations contained in the Circular number B.5/51/AS.0202/I/2020 issued by the Directorate General of Labor Inspection and occupational safety and health as an effort to prevent the spread of the virus COVID-19 in the Rembang Post Office environment. At the beginning of the Circular, the Occupational Safety and Health regulations were disseminated during the COVID-19 pandemic known as the 3M health protocols, namely putting on mask, washing hands, and social distancing. However, along with the development of the handling of the COVID-19 pandemic carried out by the government, the Occupational Safety and Health regulations during the COVID-19 pandemic were known as $5 \mathrm{M}$ namely putting on mask, washing hands, social distancing, staying away from crowds, and reducing mobility.

\section{Implementation of the COVID-19 Prevention Protocol at Rembang Post Office}

The 5M health protocols that have been implemented by Rembang Post Office include: 1) putting on mask (it is mandatory for all post office employees, postal customers, or guests to wear masks; body temperature should not be more than 37.5 degrees Celsius for employees as well as postal customers who will enter Rembang Post Office; and the obligation to wear gloves for counter officers, postal couriers, and postal orangers); 2) washing hands (it is mandatory for all post office employees, postal customers, or guests to wash their hands before entering the post office and after carrying out activities; Rembang Post Office provides two sinks and hand washing soap which is placed in front of and beside the post office); 3) social distancing (it is mandatory for all post office employees to always maintain a safe distance of at least one meter; seats both during morning briefing and on duty are given a minimum distance of one meter; seats for postal customers are given a safe distance with a sticker and a cross; seats for cash social assistance fund recipients are arranged in such a way as to meet a safety distance of at least one meter; post office service counters are insulated with clear screen; spraying disinfectant liquid in the Rembang Post Office environment in collaboration with Indonesian Red Cross Rembang); 4) staying away from the crowds (to avoid congestion at the postal service counters, the counter opening hours are extended, Monday to Friday from 07.30 AM to 07.00 PM, Saturday from 07.30 AM to 04.00 PM, and Sunday from 09.00 AM to 02.00 PM; to avoid long queues during the payment of pension funds, the pension fund payment period is extended from 1-27 days of each month; the distribution of cash social assistance funds is scheduled according to the village of the recipients); 5) reducing mobility (if not urgent, post office employees are advised not to travel out of town; if there are employees returning from work outside the city, they will be self-isolated at home for fourteen days; collaborating with the Population and Civil Registration Office to carry out COD service for sending KTP, KK, or birth certificates to the address of the applicants; collaborating with several schools in Rembang Regency to send graduation certificates to the addresses of students)

\section{Challenges in Implementing Occupational Health and Safety Management Policies During the COVID-19 Pandemic}

Occupational health and safety regulations during the COVID-19 pandemic known as the 5M health protocols have a very good purpose to protect all parties from being positive for COVID-19, but they are very difficult to implement. Some of the challenges that must be faced in implementing the $5 \mathrm{M}$ health protocols in the work environment of Rembang Post Office include: 1) from the employee's perspective, there is discomfort when having to wear masks and gloves when carrying out tasks; negligence to wear masks again after having finished eating, drinking, or after ablution; inability of some employees to wear masks according to WHO health standards;
Management of Occupational Health and Safety During The Covid-19 Pandemic: Facts and Challenges 
Table 3.

Mapping the

Effectiveness

OSH Policy

Implementation
2) from the management perspective, there is no budget planning for the procurement of hand soap, medical masks, gloves, faceshields, and hand sanitizers; there is not enough time to provide occupational safety and health training/5M health protocols for post office employees so that it is done every morning briefing; 3 ) from the perspective of consumers at Rembang Post Office, most of them neglected to wear masks because they did not know the information about mandatory masks, felt uncomfortable putting on a mask, lack of funds to buy masks, lack of information about the virus pandemic COVID-19, neglected to wash hands because postal consumers know how to wash their hands only before and after eating, are not used to washing their hands before entering the post office or before doing activities, do not apply a minimum safety distance of one meter due to the customs of the Rembang people who like to shake hands upon meeting, like to discuss and chat when waiting for the queue, shift their seat position so that they are closer to fellow postal consumers; and the cash social assistance recipients who come to collect funds not according to the specified schedule even though the scheduling has been arranged in such a way as to avoid crowds at the office post.

\section{Solutions to Overcome the Obstacles in Implementing Occupational Health and Safety Management in Facing the COVID-19 Pandemic}

Despite facing many obstacles and challenges in implementing the $5 \mathrm{M}$ health protocol, the post office is committed to implementing the health protocol properly to protect post office employees and their families as well as postal customers so that there is no cluster spread of the COVID-19 in the Rembang Post Office environment. The head of Rembang Post Office constantly promotes the $5 \mathrm{M}$ health protocol and updates information about the development of the COVID-19 pandemic to the post office employees every morning briefing. Employees reprimand, advise, and remind each other if there are other employees who are negligent of the $5 \mathrm{M}$ health protocols. The post office clerk reprimand and ask the postal customers or recipients of cash social assistance funds who do not wear masks to go home. Post office staff warns postal customers who shift their seats or those who sit on a seat marked with a cross to remain disciplined in maintaining a safety distance of at least one meter. Post office staff reminds postal customers to wash their hands with soap before entering the post office and after carrying out activities. The management provids masks, hand sanitizers, face shields, and gloves to the postal officers who are on duty at the time of distributing cash social assistance funds. Rembang Post Office promotes post oranger services, extended service period for pension fund payments and postal counter services, and collaborating with other parties for COD services (see Table 3. Mapping the Effectiveness of PT Pos Indonesia (Persero) OSH Policy Implementation During the Covid-19 Pandemic Period).

\begin{tabular}{|c|c|}
\hline Positive & Negative \\
\hline $\begin{array}{l}\text { 1. There is awareness of employees of Rembang } \\
\text { Post Office to be disciplined in complying } \\
\text { with health protocols for the common good. }\end{array}$ & $\begin{array}{l}\text { 1. Employees of Rembang Post Office feel } \\
\text { uncomfortable when working with masks and } \\
\text { gloves. }\end{array}$ \\
\hline $\begin{array}{l}\text { 2. There is an active role from the management } \\
\text { of Rembang Post Office to promote health } \\
\text { protocols. }\end{array}$ & $\begin{array}{l}\text { 2. There are difficulties in socializing the } 5 \mathrm{M} \text { health } \\
\text { protocols to post customers, especially for the } \\
\text { implementation of social distancing, which is } \\
\text { influenced by the culture of the people in the city } \\
\text { of Rembang who like to socialize. }\end{array}$ \\
\hline $\begin{array}{l}\text { 3. There is cooperation between management, } \\
\text { employees, and post customers so that the } 5 \mathrm{M} \\
\text { health protocol can be implemented properly } \\
\text { so that it does not become a cluster of } \\
\text { COVID- } 19 \text { transmission. }\end{array}$ & 3. There are additional expenses to buy masks. \\
\hline $\begin{array}{l}\text { 4. There is empathy for employees of Rembang } \\
\text { Post Office to remind and reprimand each } \\
\text { other if there is a violation of the } 5 \mathrm{M} \text { health } \\
\text { protocols. }\end{array}$ & \\
\hline $\begin{array}{l}\text { 5. The pickup service program (Oranger Post) is } \\
\text { becoming popular to the people of the city of } \\
\text { Rembang and is increasingly being used by } \\
\text { post customers during the pandemic. }\end{array}$ & \\
\hline $\begin{array}{l}\text { 6. The existence of service innovations from } \\
\text { Rembang Post Office so that there is not good }\end{array}$ & \\
\hline
\end{tabular}


With the COVID-19 pandemic, the Rembang branch post office is serious about implementing occupational health and safety by implementing the $5 \mathrm{M}$ health protocol. The head of the Rembang post office actively disseminates the $5 \mathrm{M}$ health protocol every morning. Rembang branch post office employees remind each other if there are post office employees or customers who neglect the $5 \mathrm{M}$ health protocol for the common good. the more disciplined employees carry out the health protocol, the employee's performance increases by showing the enthusiasm of the employees at work, the employees rarely get sick leave, the employees can complete their duties and responsibilities on time. The level of employee satisfaction has also increased which is shown by employees feeling calm at work even in the COVID-19 pandemic situation because the 5M health protocol facilities have been fulfilled.

\section{CONCLUSION}

The occupational health and safety management policies implemented by Rembang Post Office to face of the COVID-19 pandemic and its implications are the 5M health protocols, namely putting on a mask, washing hands, social distancing, staying away from crowds, and reducing mobility. This is in accordance with the Circular Number B.5/51/AS.0202/I/2020 from the Directorate General of Labor Inspection and occupational safety and health. Challenges faced in implementing the $5 \mathrm{M}$ health protocol policy in dealing with the COVID-19 pandemic include the discomfort of using masks and gloves while working; negligence to wash hands before entering the post office; negligence to wear a mask again after performing ablution or after eating and drinking; constraints on the provision of hand soap, medical masks, and latex gloves; constraints on regularly spraying disinfectants; and difficulty in implementing safe distance due to the social culture of the people in Rembang. Several factors influence the constraints in implementing health protocols, including the lack of public awareness of the importance of adhering to the 5M health protocols, low community discipline, low level of education of some of the people of Rembang Regency, the culture and habits of the people in Rembang Regency that are difficult to adapt to new habits/5M health protocols that have been established by the government, and the relatively low economic capacity of the people to buy masks. Solutions to overcome the obstacles in the implementation of occupational health and safety management in dealing with the COVID-19 pandemic at Rembang Post Office include: 1) always promoting the $5 \mathrm{M}$ health protocols and the importance of implementing the $5 \mathrm{M}$ health protocols for the company, employees, and customers to protect the postal employees and their families as well as postal customers from the COVID-19,2) reminding and reprimanding each other in case of violations of health protocols, 3 ) extending the retirement fund payment periods 4) extending post counter opening hours, 5) maximizing and promoting post oranger services.

In this study, the researchers found that the company paid attention to the occupational health and safety merely because they want to get an occupational safety and health certification (OHSAS 18001) or fear of an occupational safety and health audit caused by a high number of work accidents or low level of employee health. However, due to the COVID-19 pandemic, the management of occupational health and safety inevitably requires the company to implement the 5M health protocols properly to prevent the spread of the COVID-19 in the work environment. During this period of the COVID-19 pandemic, we are reminded again that the management of occupational health and safety is not only the responsibility of the company, but also the responsibility of various parties, namely employees and consumers to comply with and implement the 5M health protocols for the sake of common good. Occupational health and safety management runs well if the interests of the management, employees and consumers are well fulfilled.

The researchers found that the implementation of the $5 \mathrm{M}$ health protocols that has been carried out by all employees of Rembang Post Office every day has become a behavioral element of organizational culture (daily belief). The head of Rembang Post Office has a transformational leadership style where the head of Rembang Post Office is disciplined to implement the $5 \mathrm{M}$ health protocosl and invites all employees of Rembang Post Office during morning briefing to be disciplined in implementing health protocols so that Rembang Post Office does not become a cluster for the spread of the COVID-19 in order to maintain the good image of Rembang Post Office. This study also proved that occupational health and safety does not have a direct influence on employee performance (Ekowati \& Amin, 2018) and occupational health and safety management systems can improve occupational health and safety conditions and support the creation of a healthy and safe workplace (Mohammadfam et al., 2017).

The COVID-19 pandemic has forced companies, especially post offices, as public service offices to comply with occupational health and safety by being disciplined in carrying out health protocols. The existence of discipline in carrying out health protocols indirectly improves employee performance. Improved employee performance indirectly affects employee satisfaction. 5M health protocol can be implemented properly if there is good cooperation between post office management, employees, and postal customers.

\section{Management of Occupational Health and Safety During The Covid-19 Pandemic: Facts and Challenges}




\section{Limitations}

Some of the limitations of this study include: 1) the researchers do not get access to attendance list data, for example data on the number of post deliveries to see the performance level of post employees during the pandemic, which caused the discussion to be based only on interviews; 2) the researchers did not get permission to access the data on the number of occupational accidents and health that occur at Rembang Post Office; 3 ) the COVID-19 pandemic and limited signal access in Rembang Regency and the smartphone technology used by the community in Rembang Regency resulted in the researchers unable to distribute questionnaires (in the form of Googe Forms/online form) to the informants.

\section{Recommendation}

The researchers suggested the management of Rembang Post Office distribute vitamin C supplements and carry out regular health checks to the employees of Rembang Post Office to motivate post office employees to maintain their health; if they see post office customers coming to the branch post office and not putting on a mask, it is better if they are not sent home or prohibited from entering the post office but given a mask for free (this, in addition to educating the postal customer about the $5 \mathrm{M}$ health protocols, provides a good image and concern for postal customers); preferably a sign on the waiting room is not in English, but in the language that is easily understood by the community, for example: "Nuwun Sewu Lur Ojo Dilungguhi Kanggo Jogo Kesehatane Bareng-Bareng"; the post office management should include indicators of compliance with the 5M health protocols as an indicator of employee performance appraisals to motivate them to be more disciplined in implementing the $5 \mathrm{M}$ health protocols; and this research should be continued using quantitative methods to make it easier for policy makers.

\section{References}

Ahmad, I., Sattar, A., \& Nawaz, A. (2017, January-March). The Mediating Role Received Job Satisfaction in The Relationship betwen Occupational Health and Safety and Employees Performance. Gomal Journal of Medical Science, 15.

Dessler, G. (2016). Managemen Sumber Daya Manusia (14th ed.). Jakarta: Salemba Empat.

Ekowati, V. M., \& Amin, F. M. (2018). The Effects of Occupational Health and Safety on Employee Performance throught Work satisfaction. Advances in Economics, Business and Management Research, 101.

Goniewicz, K., Menesh, A. K., Hertelendy, A. J., Goniewicz, M., Naylor, K., \& Burkle Jr., F. M. (2020). Current Response and Management Decisions of The European Union to The COVID-19 Outbreak : A Review. Sustainability, 12(Doi : 10.3390/su12093838).

Hamzah, A. (2020). Metode Penelitian Fenomenologi Kajian Filsafat \& Ilmu Pengetahuan. Batu Malang: Literasi Nusantara.

Jumlah KPM Penerima Dana Bantuan Sosial Tunai Melalui Pos Rembang. (n.d.). Retrieved from http://www.rembangkab.go.id/bansos-bantuan-sosial/

Kaynak, R., Toklu, A. T., Elci, M., \& Toclu, I. T. (2016). Effects of Occupational Healthy and Safety Practicess on Organizational Commitment Work Alienation and Job Performance : Using The PLS-SEM Approach. International Journal of Business and Management, 11.

Mohammadfam, I., Kamalinia, M., Momeni, M., Golmohammadi, R., Hamidi, Y., \& Soltania, A. (2017). Evaluation of The Quality of Occupational Health and Safety Management System Based on Key Performance Indicators in Certified Organization. Safety and Health at Work, 8 (Doi : 10.1016.j.shaw.2016.09.001).

Panggabean, M. S. (2016). Manajemen Sumber Daya Manusia (2nd ed.). Tangerang Selatan: Universitas Terbuka.

Perkembangan Kasus Aktif Covid-19 di Kabupaten Rembang. (n.d.). Retrieved from https://www.covid19.rembangkab.go.id

Purnama, C. (2017, Okt). Emotional Inteligence and Occupational Health Impact on Employee Performance. Jurnal Ilmiah Manajemen, VIII. 
Putri, D. O., Triatmanto, B., \& Setiyadi, S. (2018). The Effect of Occupational Health and Safety Work Environment and Discipline on Employee Performance in a Consumer Goods Company. Material Science and Engineering, 8(Doi : 10.1016/j.shaw.2016.09.001).

Relation, P. (2020, March 20). Pos Indonesia Terapkan Protokol Antisipas Penyebaran Covid-19. Retrieved May 1, 2020, from http://www.posindonesia.co.id

Ridley, J. (2018). Keselamatan dan Kesehatan Kerja (3th ed.). Jakarta: Erlangga.

Sari, D. N. (2018). Pengaruh Keselamatan Kerja dan Lingkungan terhadap Kinerja dengan Kepuasan Kerja sebagai Variabel Intervening pada PT Kusuma Nanda Putra. Yogyakarta: Universitas Islam Indonesia.

Sembe, F., \& Ayuno, A. (2017). Effect of Selected Occupational Health and Safety Management Practicess on Job Satisfaction of Employees in University Campuses in Nakuru Town, Kenya. Journal Of Human Resource Management, 5 (Doi : 10.11648/jhrm.20170505.11), 70-77.

Sewu, G. J., Gyabeng, E., Dadzie, A. A., \& Nkrumah, N. K. (2019). The Effects of Occupational Health and Sfety Manageent on Performan in The Banking Sector, Ghana. International Journal of Business and Management, 14 (Doi : 10.5539/ijbm.v14n10p172).

Sobirin, A. (2016). Perilaku Organisasi. Tangerang Selatan: Universitas Terbuka.

Wibowo, E., \& Utomo, H. (2016, Juli). Pengaruh Keselamatan Kerja dan Kesehatan Kerja terhadap Kinerja dengan Kepuasan Kerja sebagai Variabel Intervening. Among Makarti, 9.

Konsep Kesehatan dan Keselamatan Kerja. Retrieved from https://www.ilo.org/global/publications

Protokol Kesehatan 5M dan Delapan Cara Pencegahan Terinfeksi Virus Covid-19. (2021). Retrived from https://www.padk.kemkes.go.id
Management of 